\title{
CHARACTERIZATION OF Fusarium oxysporum ISOLATES AND RESISTANCE OF PASSION FRUIT GENOTYPES TO FUSARIOSIS ${ }^{1}$
}

\author{
LETÍCIA MAGALHÃES TEIXEIRA², LÍSIAS COELHO ${ }^{3 *}$, \\ NILVANIRA DONIZETE TEBALDI ${ }^{3}$
}

\begin{abstract}
Passion fruit wilt, caused by Fusarium spp., is one of the most severe diseases for this crop. Although yellow passion fruit is propagated mostly by seeds, the use of rootstocks tolerant to early death could be a management strategy for cultivation in areas with disease history. Thus, this study characterized Fusarium isolates obtained in Triângulo Mineiro and determined the most suitable genotype to use for grafting to reduce losses caused by this pathogen. Mycelial growth and sporulation of Fusarium isolates, in three different growth media, was quantified by measuring colony diameter and by counting the conidia in Neubauer chamber 10 days after growth in malt extract-agar $\%$, PDA or CMA at $22 \pm 3^{\circ} \mathrm{C}$ and 12 hours lighting. Five days later the color of the colonies was evaluated. The experimental design was a $4 \times 3$ factorial completely randomized design, with five replications. Characterization of morphological structures of isolates was done with minimum cultivation in Malt extract-agar $2 \%$ amended with sterilized soil + sand $(1: 1)$. Three Passiflora species and two seedling types were used as rootstock to evaluate field resistance to fusariosis, in a randomized block design, as a $3 \times 2$ factorial, with three Passiflora species (P. alata, $P$. setacea and $P$. edulis) and two seedling types (ungrafted or grafted with $P$. edulis). The medium PDA was the least favorable for mycelial growth of the isolates. The best medium for conidium production was Malt extract and the most sporulating isolates were Fus-01 and Fus-02. Isolate color varied from white to pink to violet. Only Fus-02 and Fus-04 formed macro and microconidia. Shape, dimensions and septa number of macroconidia and microconidia, as well as the presence of characteristic monophyalides allowed the classification of all isolates as Fusarium oxysporum f.sp. passiflorae. Passiflora alata and P. setacea, used as rootstocks for $P$. edulis in the field, were resistant to fusariosis. Despite its low survival, $P$. edulis grafted on itsef, promoted similar growth of secondary branches as $P$. setacea in the field.
\end{abstract}

Index Terms: grafting, fusarium wilt, yellow passion fruit.

\section{CARACTERIZAÇÃO DE ISOLADOS DE Fusarium oxysporum E RESISTÊNCIA DE GENÓTIPOS DE MARACUJAZEIRO À FUSARIOSE}

RESUMO-A murcha do maracujazeiro causada por Fusarium spp., é uma das mais severas doenças na cultura. O maracujá-amarelo é propagado predominantemente por via sexual, entretanto, a utilização de porta-enxertos tolerantes à morte prematura de plantas pode viabilizar o seu plantio mesmo em áreas com histórico da doença. O objetivo deste trabalho foi caracterizar isolados de Fusarium spp. existentes na região do Triângulo Mineiro e determinar o melhor genótipo a ser utilizado para reduzir perdas com a doença causada por este patógeno. O crescimento micelial e a quantificação da esporulação dos isolados, em três diferentes meios, foi determinada medindo-se o diâmetro da colônia micelial e pela contagem de conídios na câmara de Neubauer respectivamente, após 10 dias de incubação em extrato de malte 2\%, PDA e CMA. Cinco dias após a avaliação do crescimento micelial observou-se a coloração das colônias. O experimento foi conduzido em esquema fatorial $4 \times 3$ (quatro isolados e três meios) com 5 repetições. A caracterização das estruturas morfológicas dos isolados foi realizada em cultivo mínimo composto pelo meio de Malte a 2\% com solo+areia autoclavados na proporção de 1:1. Três espécies de Passiflora e 2 tipos de mudas foram utilizadas como porta-enxerto para avaliar a resistência à fusariose, em delineamento de blocos casualizados com quatro repetições em esquema fatorial $3 \times 2$, sendo três espécies do gênero Passiflora ( $P$. alata, $P$. setacea e $P$. edulis) e dois tipos de mudas do tipo pé franco ou enxertadas com P. edulis. O PDA foi o meio menos favorável para o crescimento micelial dos isolados. O melhor meio para a produção de conídios foi o Extrato de Malte e os isolados mais esporulantes foram Fus-01 e Fus-02. Na caracterização morfológica as colorações dos isolados nos meios de cultura estudados variaram entre branco, rosa, roxo e violáceo. Apenas Fus-02 e Fus-04 formaram macro e microconídios. Os formatos, dimensões e número de septos dos macro e microconídios, bem como as características das monofiálides permitiram classificar todos isolados como Fusarium oxysporum f.sp. passiflorae. No campo, Passiflora alata e P. setacea usados como porta-enxerto para $P$. edulis, se mostraram mais resistentes à fusariose. Apesar da baixa sobrevivência, $P$. edulis enxertado sobre a mesma espécie promoveu crescimento dos ramos secundários semelhante ao $P$. setacea.

Termos para indexação: Enxertia, murcha de fusarium, maracujá-amarelo.

(Paper 276-15). Received December 08, 2015. Accepted July 07, 2016.

${ }^{2}$ Agr. Eng., Graduate student in Agricultural Sciences Program, UFU. E-mail: leticia_agro@hotmail.com, Capes fellowship.

${ }^{3}$ Faculty, at Instituto de Ciências Agrárias, Universidade Federal de Uberlândia, Campus Umuarama, Uberlândia-MG, Brasil. E-mails: lisias@ufu.br*(corresponding author); nilvanira.tebaldi@ufu.br. 


\section{INTRODUCTION}

Passion fruit belongs to the family Passifloraceae, widely distributed around the tropics, with more than 580 species, mostly native from tropical America (LIMA and GUERREIRO, 2007).

Brazil is main passion fruit producer in the world, with a production of 776,097 metric tons in 2012 , in an area of 57,848 hectares (IBGE, 2014), and the sour passion fruit is the most planted in the country (MELETTI, 2011). Despite its prominent position, Brazilian average yield is low (11.8 $\mathrm{t}^{\text {ha }}$ ${ }^{1}$ ), compared to the production potential of crop, estimated at 40 to $50 \mathrm{t} \mathrm{ha}^{-1}$ (MELETTI et al., 2000; FREITAS et al., 2011). Such low average is due to the expansion of the planted area simultaneously to the appearance and, or, worsening of a significant number of diseases. Such sanitary problems have reduced the economic production period and, even making growth of this species uneconomical in certain regions (FISCHER et al., 2005).

The main diseases affecting passion fruit profitability are: bacteriosis (Xanthomonas axonopodis pv. passiflorae (Pereira) Gonçalves and Rossato), fruit woodiness virus (Passionfruit Woodiness Virus- $P W V$ or Cowpea aphid-born mosaic virus - CABMW), antracnosis (Colletotrichium gloeosporioides (Penz). Penz and Sacc.) and fusarium wilt (Fusarium oxysporum f.sp. passiflorae Gordon) (FALEIRO et al., 2005). Fusarium wilt is considered as the most complex among all diseases (RONCATTO et al., 2004). According to Viana and Costa (2003), the species $F$. solani and F. oxysporum are the most damaging ones to passion fruit crop.

Fusarium wilt, also known as 'fusariosis' or 'sudden death', starts with branch yellowing and wilt, until the whole plant dries, as a consequence of root and collar rot (FISCHER et al., 2010). The disease is observed in adult plants; however, under favorable conditions, such as soils with a disease history, and high temperature and moisture, young plants can die under the pathogen attack (PONTE et al., 1998). Disease control, to the present, is done preventively since there is no effective curative measure for it. Fisher and Resende (2008) recommended avoiding planting passion fruit in areas with disease history, or in heavy and compacted soils, planting healthy seedlings, reducing wounding of collar and root system, and roguing diseased plants, thus reducing inoculum sources.

An important demand for plant breeding is for genotypes resistant to fusariosis; however, maintenance of aggressive sporulating isolates of the pathogen is difficult. In this sense, vegetative propagation brings new perspectives for cultivation of passion fruit, since harvesting in orchards has shown a reduction over the years due to phytosanitary problems caused by soilborne pathogens. Passion fruit grafting is a previously described technique (ZUCARELLI et al., 2014), and the use of resistant rootstocks, associated to other integrated management techniques, has been advocated since it is an effective, economic and ecological control measure for fusariosis (CHAVES et al., 2004; SILVA et al., 2005; CAVICHIOLI et al., 2011).

Therefore, this study characterized Fusarium spp. isolates found in the region of Triângulo Mineiro and determined the best passion fruit rootstock genotype to be used to reduce losses caused by fusariosis.

\section{MATERIAL AND METHODS}

The experiments were done at the Laboratory of Plant Pathology (LAVIV), and at the greenhouse of the Instituto de Ciências Agrárias da Universidade Federal de Uberlândia (UFU) and on a commercial passion fruit farm in Cruzeiro dos Peixotos, municipality of Uberlândia, MG.

\section{Fusarium spp. isolates}

The isolates of Fusarium spp. were collected in passion fruit commercial production areas in Uberlândia, District of Cruzeiro dos Peixotos (Uberlândia), Indianópolis and Prata, MG. Samples were collected from 8 to 10 wilting plants and reddish tinged vascular lesions, characteristic of fusariosis (Table 1).

Symptomatic stems were rinsed in water and neutral detergent. Fragments from the lesion border were cut, disinfested in alcohol $50 \%$ and sodium hypochlorite at $0.5 \%$, for 30 and 60 seconds, respectively, rinsed in sterile distilled water and transferred to Petri plates containing PDA (potato, dextrose and Agar).

The Petri plates were incubated at $22 \pm$ $3^{\circ} \mathrm{C}$ and 12 hours lighting, for 10 days, to allow myceliogenic growth of the fungus. The confirmation of Fusarium sp. was done by confirming the presence of conidia and the pinkish colony color, characteristic of Fusarium sp.

Plates with bacterial contamination had mycelium fragments transferred to Van Tieghem cells, in PDA amended with ampicillin $(250 \mathrm{mg}$ $\left.\mathrm{L}^{-1}\right)$ and rifampicin $\left(10 \mathrm{mg} \mathrm{L}^{-1}\right)$ and incubated as previously described.

Isolate preservation was done in CMA 
(Corn Meal Agar), with mycelium plugs free of contamination, and were stored at $20^{\circ} \mathrm{C}$.

\section{Seedling production}

Seedlings of P.edulis were grown at Flora Brazil Nursery, in Araguari-MG, in $100-\mathrm{cm}^{3}$ plastic cells containing a commercial substrate for plants Bioplant $^{\circledR}$, consisting of vermiculite, coconut fiber and pine bark, and cultivated in a greenhouse for 45 days. Subsequently, the seedlings were transplanted to $500 \mathrm{~mL}$ plastic cups containing the same substrate.

\section{Pathogenicity test of the isolates}

The four isolates were inoculated on 45 days old $P$. edulis seedlings by wounding the seedling collar with an autoclaved tooth pick which had been incubated over the isolate for 7 days in Malt Extract at $2 \%$. Each isolate was inoculated on 5 plants. A set of control plants was subjected to wounding with sterile tooth picks, and a second set was left with no wounding and no inoculation.

Pathogenicity evaluation was done 45 days after inoculation by sectioning the stems along the plant axis to observe lesions on the vascular bundle. Symptomatic tissues were transferred to PDA, to confirm Koch's postulates.

\section{Mycelial diameter and isolate sporulation in different growth media}

The four isolates were transferred to 3 different growth media, malt extract $2 \%$, PDA and CMA, in a $4 \times 3$ factorial experimental design, with 5 replications, considering one Petri plate per replication. The plates were incubated at $22 \pm 3^{\circ} \mathrm{C}$ and 12 hours lighting to favor myceliogenic growth of the fungus.

Evaluation was done after one of the isolates had completely covered the growth medium in one of the media evaluated, which occurred after 10 days. Measurement of colony diameter was done in two orthogonal directions and the average was determined for each replication. Conidia production was quantified from a $1 \mathrm{~cm}$-diameter mycelial disk, from the center of each plate, in a $1 \mathrm{~mL}$ suspension in sterile distilled water, using a Neubauer counting chamber. Two counts were done for each suspension.

\section{isolates \\ Morphological characterization of the}

Morphological characterization of the isolates was done by the analysis of reproductive and vegetative structures of the fungus. The isolates were grown using minimum cultivation technique, in which mycelial fragments of the isolates were placed on a disk of Malt Extract 2\% over a microscope slide, containing sterilized soil and sand at 1:1 and covered with cover glass, promoting an environment favorable for development and sporulation of Fusarium sp.

Microscope slides with the reproductive structures from minimum cultivation were observed and photographed in a light microscope (Olympus BX51, coupled with a camera Olympus DP70), showing shape and size of microconidia; size and septation of macroconidia, presence of isolate or chain chlamidospores.

Culture characteristics were evaluated 15 days after the plates were prepared, considering colony color. The experimental design was completely randomized $4 \times 3$ factorial, with five replications, containing four isolates and three different growth media.

\section{Evaluation of passion fruit genotypes for resistance to fusariosis}

Cultivar FB300 is a material selected for industry and used in hypocotyledonary grafting, considering stem diameter compatibility with the rootstock. It is commonly formed in plastic tube cells $\left(100 \mathrm{~cm}^{3}\right)$ containing commercial substrate Bioplant ${ }^{\circledR}$, which is prepared with vermiculite, coconut fiber and pine bark.

The species used as rootstocks were Passiflora setacea, P. alata and P. edulis. Seeds of P. setacea (BR Pérola do Cerrado) were provided by Embrapa Produtos e Mercado while those of $P$. alata and $P$. edulis (FB 300) were from the nursery seedbank. Sanitary management for seedling production was the standard of the nursery, with insecticides, fungicides, and foliar fertilization whenever necessary.

\section{Field experiment}

The field experiment was done in commercial production farm at the district of Cruzeiro dos Peixotos, located at $18^{\circ} 41^{\prime} 35.898^{\prime \prime} \mathrm{S}$ and $48^{\circ} 23^{\prime}$ 23.266" W, in Uberlândia-MG. The area chosen for the experiment had a history of fusariosis, causing serious losses to the owner. Thus, the plots were set in an area with generalized distribution of the pathogen, considering recurrent death of passion fruit plants in that location (Table 2).

Treatments were distributed in a $3 \times 2$ factorial, in randomized block design, consisting of three Passiflora species (P. alata, P. setacea and P. edulis) and two seedling types (ungrafted or grafted with $P$. edulis), with four replications. Each plot contained five plants, in a planting space of $3.0 \mathrm{~m}$ between plants and $3.5 \mathrm{~m}$ between rows. Transplanting to 
the field was done on 08 November 2014. Sanitary treatments, commonly done in the crop to reduce defoliation and death caused by other diseases and pests, were done. No fungicides were applied via soil drenching or spraying.

Fertilization was done with $20 \mathrm{~L}$ cattle manure, $0.3 \mathrm{~kg}$ super simple phosphate, $10 \mathrm{~g}$ zinc sulfate and $5 \mathrm{~g}$ boric acid, per planting hole, mixed with the soil one month prior to transplanting. Nitrogen and potassium were applied by fertigation.

The plants were grown in the espalier system with a single wire, fixed in 2-m long poles. Pruning was done to ensure that a single stem would grow to the wire, when the apical meristem was pruned, allowing two secondary branches to grow, one on each side of the wire.

\section{Plant evaluation in the field}

All plants with fusariosis symptoms were collected ninety days after transplanting and taken to the laboratory for isolation of Fusarium sp. from stem tissue, confirming its incidence. Fragments from the border of the lesions were removed, disinfested in $50 \%$ alcohol and $0.5 \%$ sodium hypochloride, for 30 and 60 seconds, respectively, rinsed in sterile distilled water and transferred to Petri plates containing selective medium for Fusarium, containing Peptone $\left(15 \mathrm{~g} \mathrm{~L}^{-1}\right)$, potassium phosphate (1.0 $\left.\mathrm{g} \mathrm{L}^{-1}\right)$, magnesium sulphate $\left(500 \mathrm{mg} \mathrm{L}^{-1}\right)$, PCNB $\left(1.0 \mathrm{~g} \mathrm{~L}^{-1}\right)$ and agar $\left(20 \mathrm{~g} \mathrm{~L}^{-1}\right)$, and were incubated at $25^{\circ} \mathrm{C}$ for 10 days.

The presence of Fusarium sp. was confirmed after growth in the selective medium, and the number of dead plants with fusariosis was determined. Secondary branches of surviving grafted plants were measured after they reached wire height.

\section{Statistical analyses}

Colony diameter data, and average secondary branch length, from the grafting field test, met the assumptions of normality and homogeneity by Shapiro-Wilk's and Levene's test, respectively, at $5 \%$ significance. The averages were compared by Tukey's test at $5 \%$ probability.

The number of conidia did not meet the assumptions of normality and homogeneity and were submitted to Friedman's test, a non-parametric test involving a statistical order, allowing testing a contrast between two or more treatments (MUNIZ, 1995)

\section{RESULTS AND DISCUSSION}

Pathogenicity of Fusarium spp. isolates

No visible changes were observed on the external bark of seedlings 45 days after inoculation. The stems of P.edulis were sectioned lengthwise and darkening of internal tissues was observed near the inoculation site. The inoculated isolates were recovered from the lesions, confirming Koch's postulates, and no other pathogenic fungus was associated to the lesions, thus confirming that all four isolates were pathogenic to passion fruit.

Sporulation of Fusarium spp. isolates in different growth media

The results showed significant variation in conidia production in the different culture media (Table 3). The best medium for conidia production was malt extract, while PDA and CMA were less effective for spore production, being less favorable for the formation of such structures. Fusarium sp. spore formation in malt extract was $1.6 \times 10^{6}$ conidia. When the media CMA and PDA are contrasted, no difference in spore number is found. Silva and Teixeira (2012), studying the sporulation of $F$. solani, found $2.19 \times 10^{3}$ to $4,13 \times 10^{3}$ conidia $\mathrm{mL}^{-1}$, and that such differences were due to different lighting regimes.

Considering the effect of different media on isolate sporulation, it was observed that malt extract is very interesting for the production of large amount of inoculum, demonstrating that there are differences in nutrient use by the fungi. The medium PDA presents great nutritional richness and greater amount of complex carbohydrates. These characteristics can induce the reproduction of many mitosporic fungi (LUKENS, 1963; STRANDBERG, 1987), as observed by Silva and Teixeira (2012), who found greater sporulation of Fusarium solani in PDA and PSA (Potato Sucrose Agar). However, in this study, PDA and CMA were less effective for inducing the sporulation of the Fusarium spp. isolates evaluated, corroborating the results of Dhingra and Sinclair (1995) who, recommend the use of nutritionally poor media to stimulate the sporulation of fungi.

Fusarium spp. isolate sporulation was compared by counting the number of spores formed by each one of them, totalizing them for each of the three media studied (Table 4). Isolate Fus-02 differed from isolates Fus-03 and Fus-04, suggesting that it may have better ability to use the nutrients provided for the formation of reproductive structures than the other two; however, it was not different from the isolate Fus-01. The least sporulating isolates were 
Fus-04 and Fus-03, since they were similar to each other and lower than the other two.

\section{Morphology of the isolates studied}

The four isolates studied varied in all analyzed characteristics. Variations in each culture medium were color, spore types formed and mycelial growth. In general, all colonies presented vigorous growth.

Mycelial growth of Fusarium spp., in general, was greater in malt extract and CMA, with the exception of isolate Fus-01, which grew better in CMA than in any other one (Table 5). Average growth varied from 5.4 to $8.0 \mathrm{~cm}$ diameter. This was contrasting with growth in PDA which, for most isolates, led to less growth (Table 5).

Isolates Fus-02, Fus-03 and Fus-04 formed larger colonies in PDA, with averages between 5.0 and $5.4 \mathrm{~cm}$ diameter. Only Fus- 01 had lower average than the other isolates $(3.8 \mathrm{~cm})$. It is possible that PDA was the least favorable growth medium for all isolates. The two other media, malt extract and CMA, were better since they promoted greater colony diameter, except for one of the isolates.

Dariva (2011), studying characteristics of Fusarium oxysporum f.sp. passiflorae isolates, found an average mycelial growth of $6.36 \mathrm{~cm}$ in PDA after four days of incubation and color variation from white, cream and violet in different tinges at the seventh day of incubation. Although the average colony diameter of the four isolates in this study $(4.9 \mathrm{~cm})$ was smaller than that found by Dariva (2011) $(6.36 \mathrm{~cm})$, both results seem common. Such differences could be attributed to natural variability among isolates.

The cultural characteristics of the four isolates varied according the media used. In general, colonies presented vigorous growth, mycelia covering almost all the plate surface after four days and sporulation after seven days of incubation.

Colony color varied from white, pink, purple and violet (Table 6). Variation in cultural characteristics indicates that isolates change their appearance when cultivated in different media, thus suggesting that each medium supplies different nutrientes for the isolates (Figures 1 to 4).

Morphological analysis of microscopic structures of the isolates showed variation among the isolates for the production of macro and microconidia. The isolates Fus-02 and Fus-04, besides microconidia, were the only ones forming macroconidia.

Isolates Fus-02 and Fus-04 formed falciform macroconidia, usually with 4 to 5 septa (Table 7).
Also microconidia varied in shape, from elliptical to cylindrical, with 0 to 2 septa which, according to Booth (1977) identifies the isolates as Fusarium oxysporum.

Dariva (2011), in her study, showed that Fusarium solani forms cylindrical macroconidia, with no convex curvature, as seen in Fusarium oxysporum f.sp. passiflorae, suggesting that the isolates of this study are Fusarium oxysporum f.sp. passiflorae. Moreover, macroconidia shape characteristics of the isolates studied agree with those mentioned by Ciampi et al. (2009) for Fusarium oxysporum.

The average macroconidia length and width (Table 7) varied from 19.8 to $61.0 \mu \mathrm{m}$ and 3.15 to 6.0 $\mu \mathrm{m}$, respectively, among the isolates. Microconidia length varied from 5.80 to $8.05 \mu \mathrm{m}$. These results are in the range mentioned by Ciampi et al. (2009) for Fusarium oxysporum. In that publication, the authors state that macroconidia present three to five septa, and measure $27-55 \mu \mathrm{m}$ length by $3-5 \mu \mathrm{m}$ width.

The shape, dimensions, septa number of macro and microconidia and characteristics of monophialides found in this study were very similar to those of Dariva's (2011), also studying isolates of Fusarium oxysporum f.sp. passiflorae.

Microscope analysis showed that isolates Fus-01 and Fus-02 presented round chlamydospores, smooth, formed isolated or in pairs, at hyphae tips or along them (Figures 1 and 2). No chlamydospores were found in the other two isolates (Figures 3 and 4).

The Fusarium identification key proposed by Booth (1977) describes several characteristics, such as colony aspect, microconida formation structure, chlamydospore presence and characteristics, macro and microconidia presence and size. However, according to Nelson et al. (1983), the differentiating characteristics between $F$. oxysporum and $F$. solani are the morphology of macroconidia and and short monophialides $(<20 \mu \mathrm{m})$ for $F$. oxysporum and long $(>100 \mu \mathrm{m})$ for F. solani.

The isolates in this study presented phialides shorter than $20 \mu \mathrm{m}$. Thus, together with colony characteristics and microscopic structures, the four isolates studied are Fusarium oxysporum f.sp. passiflorae.

\section{fusariosis}

Resistance of passion fruit genotypes to

The first wilt symptoms and plant death were observed 90 days after transplanting. All symptomatic plants, until 180 days after transplanting, were plated in selective media to confirm the presence of $F$. oxysporum. Passiflora edulis was completely 
susceptible, and all ungrafted plants were killed by $F$. oxysporum, leaving only $20 \%$ of that species grafted on itself (Table 8). Passiflora alata and $P$. setacea were more resistant to fusarioris than $P$. edulis. Similar results were obtained by Cavichioli et al. (2011), who, evaluating six species of passion fruit in an area with sudden death history, reported the survival of $100 \%$ of $P$. gibertii and of $P$. setacea and $93 \%$ of $P$. alata, 270 days after transplanting.

Ambrosio et al. (2015), analyzing yield and survival of grafted yellow passion fruit, found greater survival, 14 months after field transplanting, in plants grafted on $P$. nitida $(93.9 \%)$, followed by $P$. alata $(81.2 \%)$ and ungrafted $P$. edulis $(77.5 \%)$.

The longest secondary branches were observed in plants grafted on P. edulis and P. setacea, which were different from $P$. alata (Table 9), 180 days after transplanting. Such results are similar to those found by Couto Junior (1976) who, in a trial of $P$. edulis f. flavicarpa grafted on itself or on $P$. alata, found that the better combination was selfgrafted P. edulis. The similarity of results from both studies indicates that there might be an incompatible interaction $P$. edulis $\mathrm{x} P$. alata for the characteristic average secondary branch length.

The best performance of $P$. edulis for average secondary branch length was expected, since rootstock and scion belonged to the same species, thus increasing compatibility, which was also observed by Nogueira Filho et. al (2010). Similarly, P. alata, being a different species, with square cross section, which is different from P.edulis, with round cross section, increases the possibility of incompatibility, or difficulty of adaptation between them.

Cavichioli et al. (2011) demonstrated that $P$. edulis grafted on $P$. edulis had better development, followed by $P$. alata and then by $P$. giberti. In that study, the characteristics analyzed that reflected into more vigorous plants were collar diameter, internode length, length of secondary branches and number of tertiary branches. Hypocotyledonary grafting of P.edulis on P.edulis was better than P.edulis grafted in any other species for all these characteristics.

These results demonstrate the need for longer evaluation time for the species and their grafting combinations since less vegetative development does not, necessarily, reflect into lower yield. The results of Cavichioli et al. (2011) determined that plants grafted on $P$. alata had smaller internodes, secondary branch length and fewer tertiary branches, resulting in less vegetative development of these plants. However, such difference was compensated during the cycle and similar yield was obtained in ungrafted $P$. edulis and those grafted on $P$. alata.

TABLE 1- List of isolates obtained in the region of Triangulo Mineiro, October 2013.

\begin{tabular}{ccc}
\hline ISOLATE & HOST & LOCATION \\
\hline Fus-01 & Passiflora edulis & Uberlândia \\
Fus-02 & Passiflora edulis & Uberlândia \\
Fus-03 & Passiflora edulis & Uberlândia \\
Fus-04 & Passiflora edulis & Indianópolis \\
\hline
\end{tabular}

TABLE 2 - Number of spores per gram of soil in each block at the experiment area Cruzeiro dos Peixotos, September 2014.

\begin{tabular}{cc}
\hline Experiment area & Number of Fusarium sp. spores $\mathbf{~ g}^{-\mathbf{1}}$ soil \\
\hline Block 1 & 206,000 \\
Block 2 & 220,000 \\
Block 3 & 292,000 \\
Block 4 & 197,000 \\
\hline Average & 228,750 \\
\hline
\end{tabular}

TABLE 3 - Contrasts of Fusarium oxysporum sporulation and their respective significance levels $(\alpha)$ involving 3 culture media.

\begin{tabular}{ccc}
\hline Contrast & Spores $\mathbf{~ m L}^{-1}\left(\mathbf{x} \mathbf{1 0}^{6}\right)$ & $\alpha$ \\
\hline CMA x PDA & $(1.1) \times(1.1)$ & Ns \\
CMA x Malt & $(1.1) \times(1.6)$ & 0.067 \\
PDA x Malt & $(1.1) \times(1.6)$ & 0.026 \\
\hline
\end{tabular}

(ns) non-significant by Friedman's test.

$(\alpha)$ significant by Friedman's test. 
TABLE 4 - Contrasts for the amount of sporulation of Fusarium oxysporum, their respective significance level $(\alpha)$ involving 4 isolates. Uberlândia, 2014.

\begin{tabular}{lcc}
\hline \multicolumn{1}{c}{ Contrast } & Spores $\mathbf{~ m L}^{-\mathbf{1}}(\mathbf{x 1 0})$ & $\alpha$ \\
\hline Fus-01x Fus-02 & $(1.25) \times(2.60)$ & $\mathrm{Ns}$ \\
Fus-01x Fus-03 & $(1.25) \times(0.48)$ & $\mathrm{Ns}$ \\
Fus-01x Fus-04 & $(1.25) \times(0.58)$ & $\mathrm{Ns}$ \\
Fus-02 x Fus-03 & $(2.60) \times(0.48)$ & 0.019 \\
Fus-02 X Fus-04 & $(2.60) \times(0.58)$ & 0.044 \\
Fus-03 x Fus-04 & $(0.48) \times(0.58)$ & $\mathrm{Ns}$ \\
\hline
\end{tabular}

(ns) non-significant by Friedman's test.

$(\alpha)$ significance by Friedman's test.

TABLE 5 - Colony diameter $(\mathrm{cm})$ of the 4 isolates of Fusarium oxysporum on 3 culture media. Uberlândia, 2014

\begin{tabular}{ccccc}
\hline Isolate & PDA & MALTE & CMA & Average \\
\hline Fus-01 & $3.8 \mathrm{cB}$ & $6.8 \mathrm{bB}$ & $8.0 \mathrm{aA}$ & 6.2 \\
Fus-02 & $5.0 \mathrm{bA}$ & $6.6 \mathrm{aB}$ & $6.6 \mathrm{aB}$ & 6.0 \\
Fus-03 & $5.4 \mathrm{bA}$ & $6.6 \mathrm{aB}$ & $7.4 \mathrm{aAB}$ & 6.4 \\
Fus-04 & $5.4 \mathrm{bA}$ & $8.0 \mathrm{aA}$ & $5.4 \mathrm{bC}$ & 6.2 \\
\hline Average & 4.9 & 7.0 & 6.8 & \\
\hline
\end{tabular}

*Averages followed by different small cap letters in the rows, and capital ones in the columns, are different by Tukey's test at $5 \%$ significance.

TABLE 6 - Colony color obtained from four Fusarium oxysporum isolates in three different culture media. Uberlândia, 2014.

\begin{tabular}{cclc}
\hline & \multicolumn{3}{c}{ Colony color } \\
\hline ISOLATE & PDA & CMA & MALT \\
\hline Fus-01 & Pink & White & White \\
Fus-02 & Light pink & White & Purple \\
Fus-03 & Light pink & White & White and purple \\
Fus-04 & Light pink & White & Violet \\
\hline
\end{tabular}

TABLE 7 - Length, width, number of septa and shape of macro and microconidia, and production of chlamydospores of Fusarium oxysporum isolates. Uberlândia, 2014.

\begin{tabular}{cccccc}
\hline \multicolumn{2}{c}{ Macroconidium } & \multicolumn{2}{c}{ Microconidium } & \\
\hline Isolate & $\mathbf{C}^{\mathbf{1}} \mathbf{\times} \mathbf{L}^{\mathbf{2}}$ & Septa & Format & $\mathbf{C}^{\mathbf{1}}$ & $\mathbf{C l a m}^{\mathbf{3}}$ \\
\hline Fus-01 & $22.2 \pm 8.4 \times 3.2 \pm 1.2$ & $4.0 \pm 1.5$ & - & - & + \\
Fus-02 & $61.0 \pm 23.2 \times 6.0 \pm 2.2$ & $5.00 \pm 1.9$ & Elliptical & $5.8 \pm 2.2$ & + \\
Fus-03 & - & - & Cylindrical & $8.1 \pm 3.0$ & - \\
Fus-04 & $19.8 \pm 7.5 \times 3.1 \pm 1.2$ & $4.00 \pm 1.5$ & Cylindrical & $8.0 \pm 3.0$ & - \\
\hline
\end{tabular}

${ }^{1}$ Length $(\mu \mathrm{m})$ and ${ }^{2}$ Width $(\mu \mathrm{m}) ;{ }^{3}$ Presence of chlamydospores Error calculated at $\alpha 0.05$.

TABLE 8 - Survival percentage of three Passiflora species cultivated as rootstock of $P$. edulis (FB 300) and as ungrafted plants in a highly infested soil with Fusarium sp. Cruzeiro dos Peixotos, Uberlândia. 2014.

\begin{tabular}{ccc}
\hline Passiflora species & Ungrafted & Grafted with FB 300 \\
\hline Passiflora alata & 90 & 90 \\
Passiflora setacea & 80 & 85 \\
Passiflora edulis & 0 & 20 \\
\hline
\end{tabular}


TABLE 9 - Average secondary branch length $(\mathrm{m})$ of yellow passion fruit grafted on three rootstocks, 180 days after transplanting in the field. Uberlândia. 2014.

\begin{tabular}{cc}
\hline Rootstock & Average branch length $(\mathbf{m})$ \\
\hline P. alata & $0.40 \mathrm{~b}$ \\
P. setacea & $1.42 \mathrm{a}$ \\
P. edulis & $2.06 \mathrm{a}$ \\
\hline
\end{tabular}

*Averages followed by different letters are different by Tukey's test at 5\% significance.

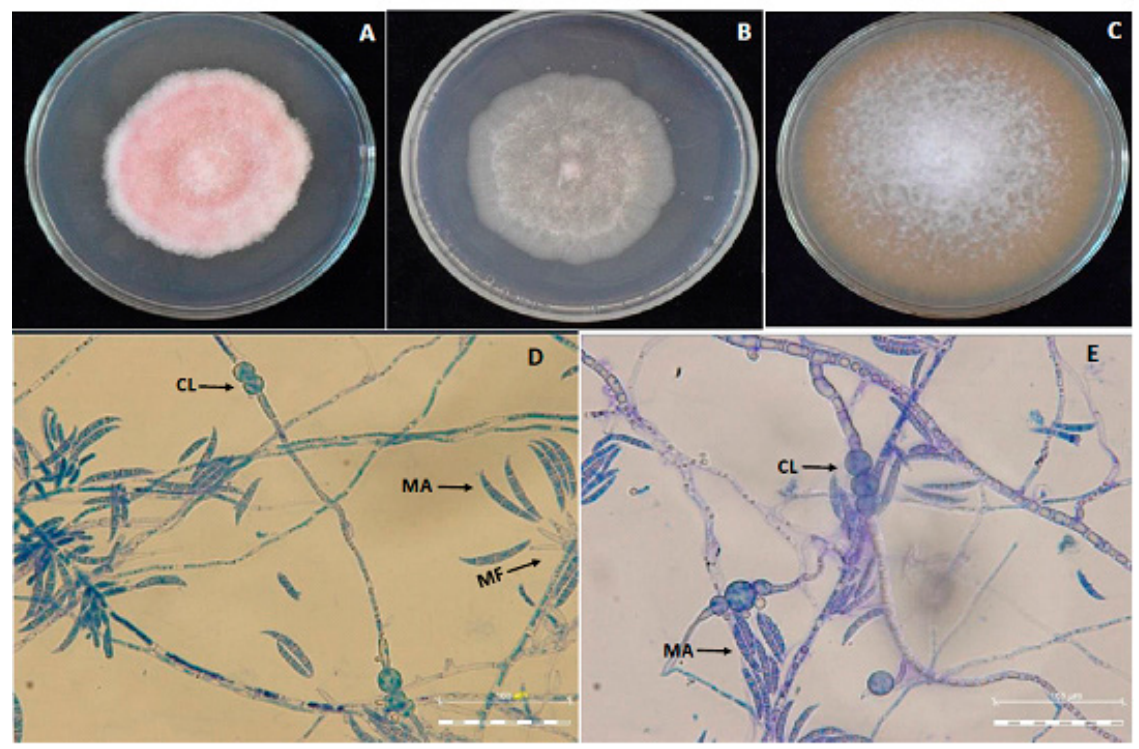

FIGURE 1 - Cultural and morphological characteristics of Fusarium oxysporum f. sp. passiflorae isolate Fus-01. A, B, C: colony aspect on PDA, CMA and MALT, respectively. D, E: Chlamydospores - CL, macroconidia - MA and monophialides - MF, obtained in MALT 2\%.

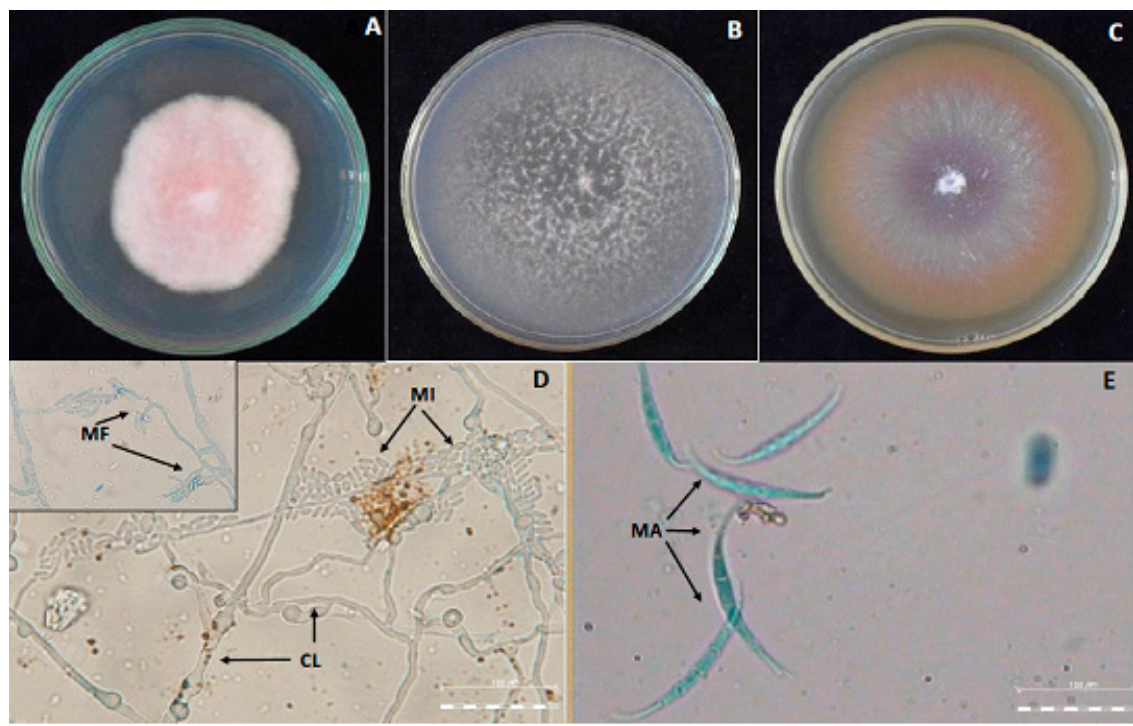

FIGURE 2 - Cultural and morphological characteristics of Fusarium oxysporum f. sp. passiflorae isolate Fus-02. A,B,C: colony aspect on PDA, CMA and MALT, respectively. D, E: Chlamydospores - CL, macroconidia - MA and monophialides - MF, obtained in MALT 2\% 


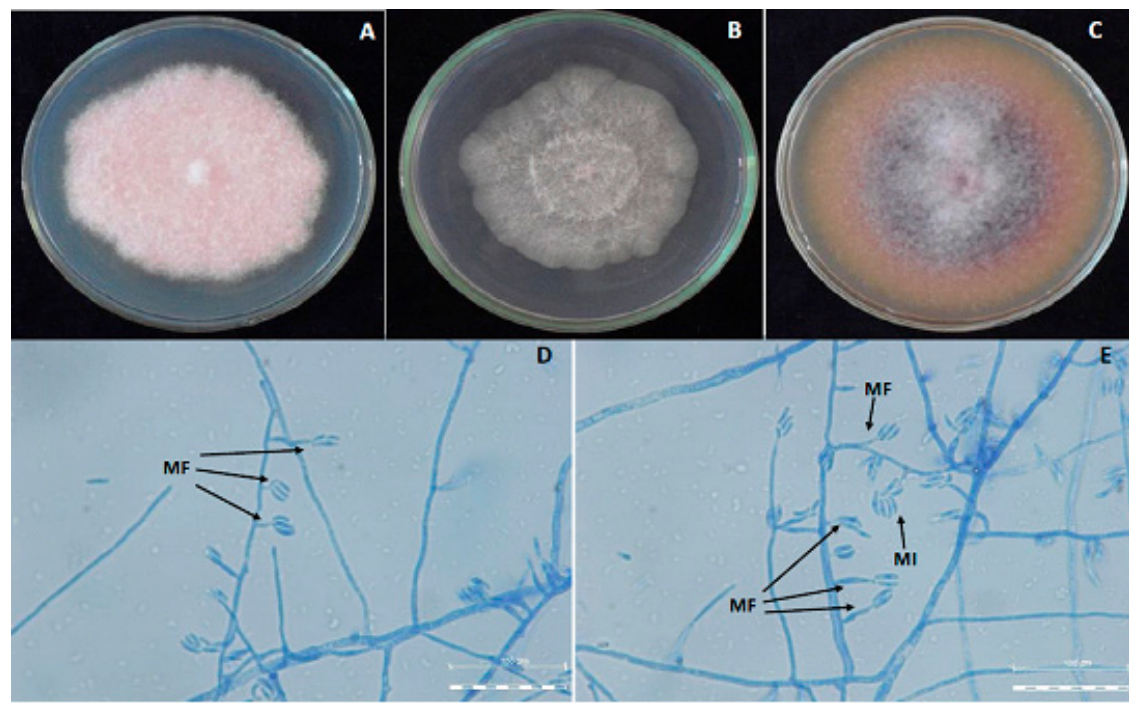

FIGURE 3 - Cultural and morphological characteristics of Fusarium oxysporum f. sp. passiflorae isolate Fus-03. A,B,C: colony aspect on PDA, CMA and MALT, respectively. D, E: macroconidia MA and monophialides - MF, obtained in MALT $2 \%$.

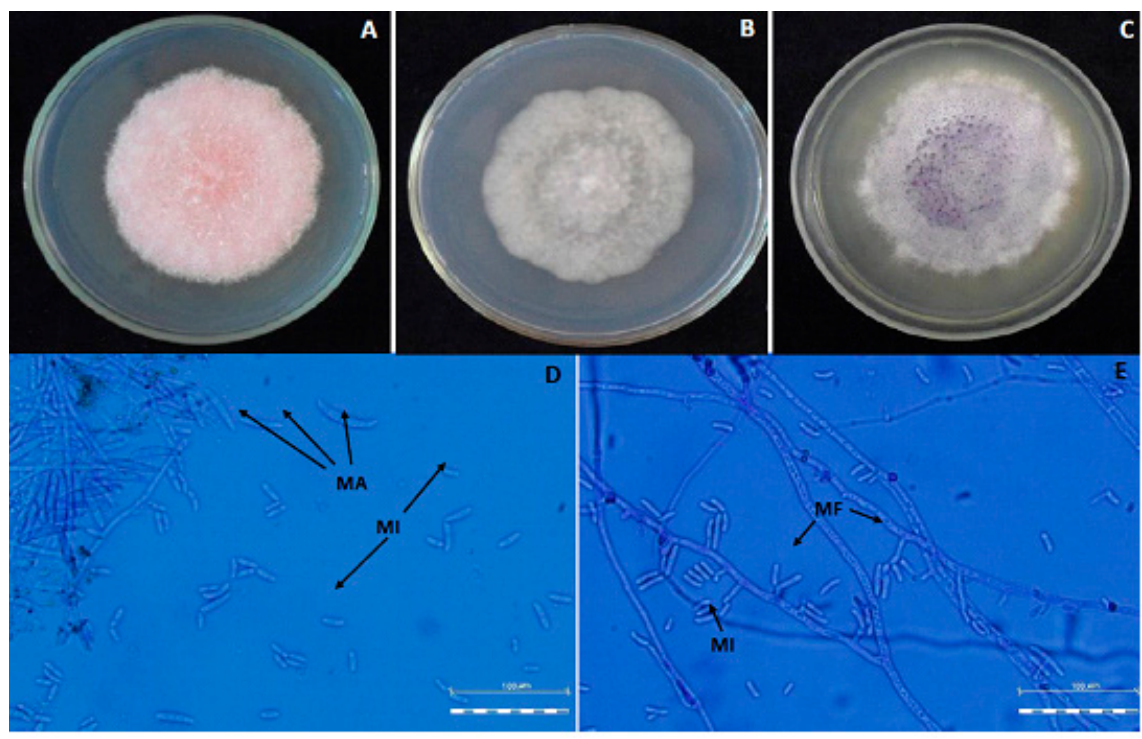

FIGURE 4 - Cultural and morphological characteristics of Fusarium oxysporum f. sp. passiflorae isolate Fus-04. A, B, C: colony aspect on PDA, CMA and MALT, respectively. D, E: macroconidia - MA and monophialides - MF, obtained in MALT 2\%. 


\section{CONCLUSIONS}

All the isolates studied were pathogenic to passion fruit, and isolates Fus-02 and Fus-01 were the most sporulating ones.

Morphological characterization of isolates confirmed them as F. oxysporum f.sp. passiflorae.

The species $P$. setacea is the best rootstock option for $P$. edulis, considering resistance to fusariosis and secondary branch development.

\section{REFERENCES}

AMBRÓSIO, M.; ARAÚJO, A.A.T.; KABEYA, K.S.; KRAUSE, W. Utilização de mudas enxertadas no controle da fusariose no cultivo do maracujazeiro azedo. Revista MT Horticultura, Tangará da Serra, v.1, n.1, p.5-7, 2015.

BOOTH, C. Fusarium: laboratory guide to the identification of the major species. Kew: Common Wealth Mycological Institute, 1977. 58 p.

CAVICHIOLI, J.C.; CORREA, L.S.; GARCIA M.J.M.; FISCHER, I.H. Desenvolvimento, produtividade e sobrevivência de maracujazeiroamarelo enxertado e cultivado em área com histórico de morte prematura de plantas. Revista Brasileira de Fruticultura, Jaboticabal, v.33, n.2, p.567-574, 2011.

CHAVES, R.C.; JUNQUEIRA, N.T.V.; MANICA, I.; PEIXOTO, J.R.; PEREIRA, A.V.; FIALHO, J.F. Enxertia de maracuajzeiro-azedo em estacas herbáceas enraizadas de espécies de passifloras nativas. Revista Brasileira de Fruticultura, Jaboticabal, v.26, n.1, p.120-123, 2004.

CIAMPI, L.; NISSEN, J.; VENEGAS, E.; FUENTES, R.; COSTA, M.; SCHÖBITZ, R.; ALVAREZ, E.; ALVARADO, P.Identification of two species of Fusarium Link that cause wilting of colored callas (Zantedeschia aethiopica (L.) Spreng.) cultivated under greenhouse conditions in Chile. Chilean Journal of Agricultural Research, Santiago, v.69, n.4, p.516-525. 2009.

COUTO JUNIOR, J.G. Efeito de combinações copa/ porta-enxerto no teor de matéria seca acumulada em maracujá. 1976. 25f. Monografia (Trabalho de Conclusão de Curso Graduação em Agronomia) - Faculdade de Ciências Agrárias e Veterinárias, Universidade Estadual Paulista, Jaboticabal, 1976.
DARIVA, J.M. Fusarioses do maracujazeiro: etiologia e sintomatologia. 2011. 71 f. Dissertação (Mestrado em Produção Vegetal no Semiárido) Universidade Estadual de Montes Claros, Janaúba, 2011.

DHINGRA, O.D.; SINCLAIR, J.B. Basic plant pathology methods. Boca Raton: Lewis Publishers, 1995. $355 \mathrm{p}$.

FALEIRO, F.G.; JUNQUEIRA, N.T.V.; BRAGA, M.F.B. Maracujá: germoplasma e melhoramento genético. Planaltina: Embrapa Cerrados, 2005. p.81-82.

FISCHER, I.H.; BUENO, C.J.; GARCIA, M.J.; ALMEIDA, A.M. Reação de maracujazeiro-amarelo ao complexo fusariose-nematoide de galha. Acta Scientiarum. Agronomy, Maringá, v.32, n.2, p.223227,2010

FISCHER, I.H.; LOURENÇO, S.A.; MARTINS, M.C.; KIMATI, H.; AMORIM, L. Seleção de plantas resistentes e de fungicidas para o controle da podridão do colo do maracujazeiro causada por Nectria hematococca. Fitopatologia Brasileira, Brasília, DF, v.30, n.3, p.250-258, 2005.

FISCHER, I.H.; RESENDE, J.A.M. Diseases of Passion Flower (Passiflora spp.) Pest Technology, Kagawa, v.2, n.1, p.1-19, 2008.

FREITAS, J.P.X.; OLIVEIRA, E.J.; CRUZ NETO, A.J.; SANTOS, L.R. Avaliação dos recursos genéticos de maracujazeiro amarelo. Pesquisa Agropecuária Brasileira, Brasília, DF, v.46, p.10131020, 2011.

GARDNER, D.E. Pathogenicity of Fusarium oxysporum f. sp.passiflorae to banana poka and other Passiflora spp.in Hawaii. Plant Disease, Saint Paul, v.73, p.476-478, 1989.

IBGE - Instituto Brasileiro de Geografia e Estatística. Produção e área de produção de maracujá: 2012. Brasília. Disponível em: <www.ibge.gov.br/> Acesso em: 23 abr. 2014.

LIMA, D. S. GUERREIRO, J. C. Germinação de sementes de maracujá-amarelo em diferentes substratos e ambientes. Revista Científica Eletrônica de Agronomia, Garça, v.6, n.11, jun. 2007. 
LUKENS, R.J. Photo-inhibition of sporulation in Alternaria solani. American Journal of Botany, New York, v.50, n.7, p.721-724, 1963.

MELETTI, L.M.M. Avanços na cultura do maracujá no Brasil. Revista Brasileira Fruticultura, Jaboticabal, v.33, n.1, p.83-91, 2011.

MELETTI, L.M.M.; SANTOS, R.R.; MINAMI, K. Melhoramento do maracujazeiro amarelo: obtenção do cultivar 'composto IAC-27'. Scientia Agrícola, Piracicaba, v.57, p.491-498. 2000.

MUNIZ, J.A. O uso da estatística experimental não-paramétrica. Lavras: UFLA, 1995. 21 p. (Seminário apresentado aos alunos do curso de pós-graduação em Agronomia - Genética e Melhoramento de Plantas).

NELSON, P.E.; TOUSON, T. A.; MARASSAS, W.F.O. Fusarium species, an illustrated manual for identification. University Park: Pennsylvania State University Press, 1983. 193p.

NOGUEIRA FILHO, G C.; RONCATTO, G.; RUGGIERO, C.; OLIVEIRA, J.C.; MALHEIROS, E.B. Desenvolvimento e produção das plantas de maracujazeiro-amarelo produzidas por enxertia hipocotiledonar sobre seis porta-enxertos. Revista Brasileira de Fruticultura, Jaboticabal, v.32, n.2, p.535-543, 2010.

PONTE, J.J.; FRANCO, A.; AGUiÁR DE HOLANDA, Y.C.; SILVEIRA FILHO, J. Calagem, adubação orgânica e fungicida de solo no controle de podridão-do-pé (Fusarium solani) do maracujáamarelo. Fitopatologia Venezolana, Maracay, v.12, n.1, p.30-31. 1998.
RONCATTO, G.; OLIVEIRA, J.C.R.C.; NOGUEIRA FILHO, G.C.; CENTURION, M.A.P.C.; FERREIRA, F.R. Comportamento de maracujazeiros (Passiflora spp.) quanto à morte prematura. Revista Brasileira de Fruticultura, Jaboticabal, v.26, n.3, p.552-554, 2004.

SILVA, F.M.; CORRÊA, L.de S.; BOLIANI, A.C.; SANTOS, P.C. dos. Enxertia de mesa de Passiflora edulis Sims f. flavicarpa Deg. sobre Passiflora alata Curtis, em ambiente de nebulização intermitente. Revista Brasileira de Fruticultura, Jaboticabal, v.27, n.1, p.98-101, 2005.

SILVA, J.L.; TEIXEIRA, R.N.V. Esporulação e crescimento micelial de Fusarium solani em diferentes meios de cultura e regimes de luminosidade. Revista Agro@mbiente, Boa Vista, v.6, n.1, p.47-52, 2012.

STRANDBERG, J. O. Isolation, storage, and inoculum production methods for Alternaria dauci. Phytopathology, St. Paul, v.77, n.7, p.1008- 1012, 1987.

VIANA, F. M. P.; COSTA, A. F. Doenças do maracujazeiro. In: FREIRE, F.C.O; CARDOSO, J.E.; VIANA, F.M.P. (Ed.). Doenças de fruteiras tropicais de interesse agroindustrial. Brasília, DF: Embrapa Informação Tecnológica, 2003. p. 276-285.

ZUCARELLI, V.; ONO, E.O.; KROHN, N.G. A enxertia na cultura do maracujazeiro: aspectos anatômicos, bioquímicos e fisiológicos. Journal of Agronomic Sciences, Madison, v.3, p.8697, 2014. Disponível em: $<$ http://hdl.handle. net/11449/137175>. 